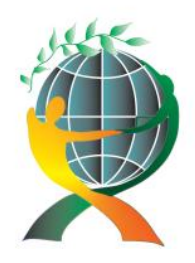

\author{
(online) $=$ ISSN $2285-3642$ \\ ISSN-L = $2285-3642$ \\ Journal of Economic Development, Environment and People \\ Volume 1, Issue 2, 2012 \\ URL: http://jedep.spiruharet.ro \\ e-mail: office jedep@spiruharet.ro
}

\title{
Sustainable energy management - a prerequisite for the realization Kyoto Protocol
}

\author{
Mirjana Golušin, University Educons, Sremska Kamenica, Serbia, mirjanagolusin@sbb.rs \\ Olja Munitlak Ivanović, University Educons, Sremska Kamenica, Serbia oljaivanovic@eunet.rs \\ Simonida Vučenov, University Educons, Sremska Kamenica, Serbia, svucenov@gmail.com
}

\begin{abstract}
Energy management can be defined as the process of planning, directing, implementing and controlling the process of generation, transmission and energy consumption. Energy management is a kind of synthesis of phenomena and concepts of modern energy management (management), or the use of modern settings management in the energy sector. Furthermore, when outlining the basic settings for power management Modern management is based on the assumptions of sustainability and conservation of energy stability for present and future generations. Therefore, modern energy management can be seen as a kind of synthesis of three actuarial sciences: energy, sustainable development and management. Sustainable Energy Management is a unique new concept, idea and approach that require many changes in the traditional way of understanding and interpretation of energy management at all levels. Sustainable energy management concept cannot therefore be construed as an adopted and defined the concept, but must be constantly modified and adjusted in accordance with changes in the three areas that define it, and in accordance with the specific country or region where applicable. Accordingly, sustainable energy management can be defined as the process of energy management that is based on fundamental principles of sustainable development.
\end{abstract}

Keywords: energy, economics, management

JEL Codes: Q13, Q40, Q48, P48 


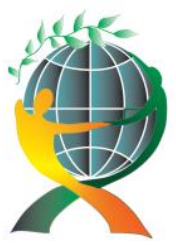

\author{
(online) $=$ ISSN $2285-3642$ \\ ISSN-L = $2285-3642$ \\ Journal of Economic Development, Environment and People \\ Volume 1, Issue 2, 2012 \\ URL: http://jedep.spiruharet.ro \\ e-mail: office jedep@spiruharet.ro
}

\title{
1. Introduction
}

Previous experience, theory and practice, clearly indicated the need to develop special mechanisms aimed at proper management of energy in all phases of its existence, at all levels in all time frames. The need for energy management has existed since ancient times in various forms, but it is only modern science and practice management, respecting the principles of sustainable development, provide an adequate framework for the implementation of the above mentioned problems. When designing the concept of sustainable energy management, it was necessary to proceed from the broadest framework that defines processes in this area, and relate primarily to two main factors that are important izuzeno, and that the size of the strategic issues that need to be addressed and assessed verme required to the proposed energy management strategy could be realized. Sustainable access to energy management and created just for these two characteristics that define it more and more powerful than a number of changes that are encountered in the history of mankind.

\section{Concept of sustainable energy management}

Energy management can be defined as the process of planning, directing, implementing and controlling the process of generation, transmission and energy consumption. Energy management is a kind of synthesis of phenomena and concepts of modern energy management (management), or the use of modern settings menažmenta in the energy sector. Furthermore, when outlining the basic settings for power management Modern management is based on the assumptions of sustainability and conservation of energy stability for present and future generations. Therefore, modern energy management can be seen as a kind of synthesis of three actuarial sciences: energy, sustainable development and management, which are interconnected and conditioned, as shown in Figure 1. 

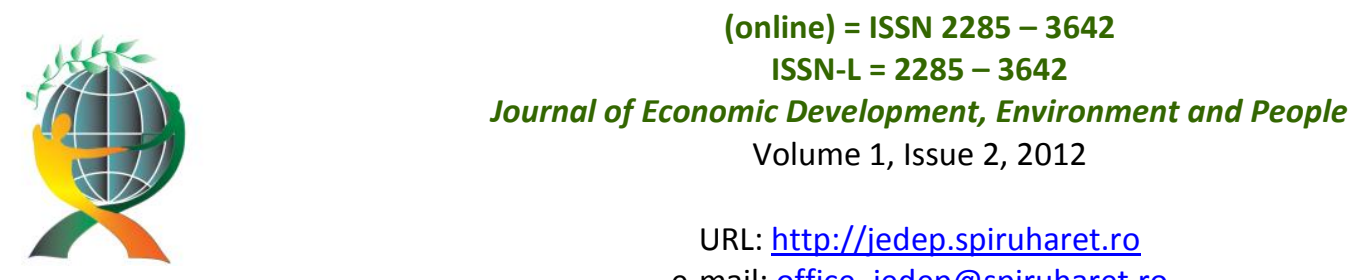

URL: http://jedep.spiruharet.ro e-mail: office jedep@spiruharet.ro

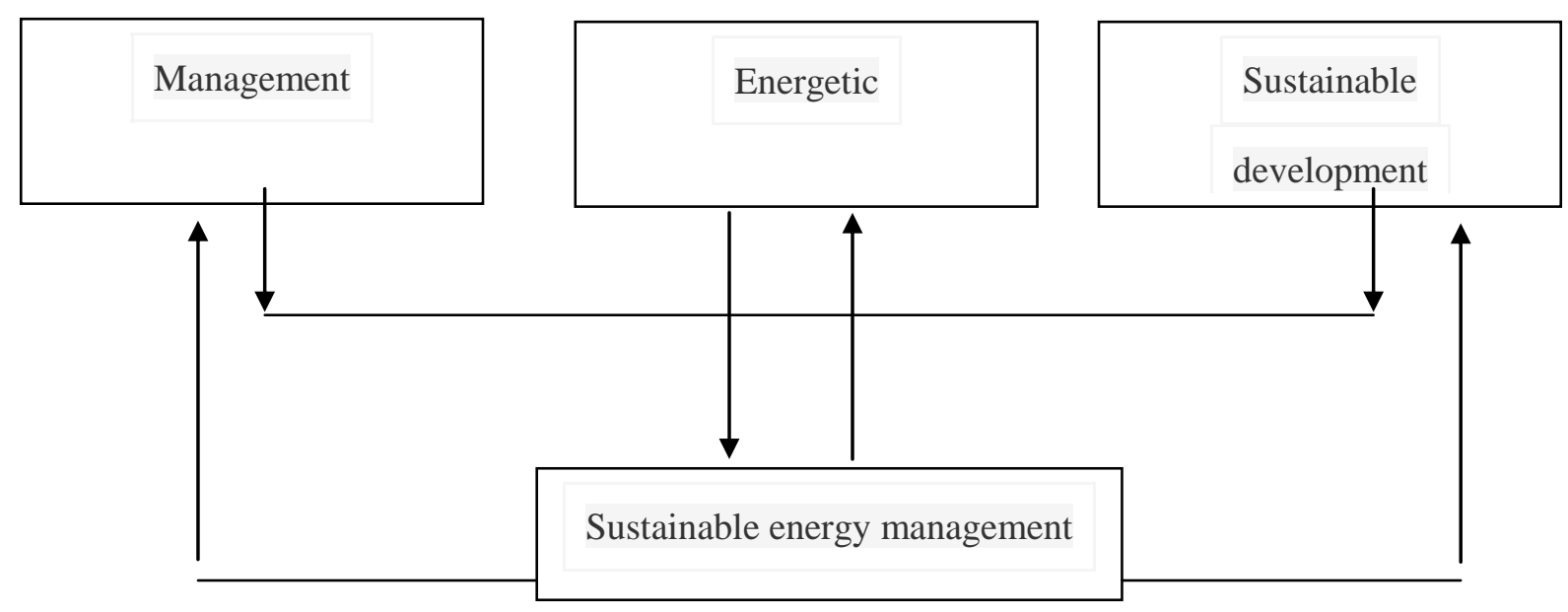

Fig. 1: The basic concept of sustainable energy management

Sustainable Energy Management is a unique new concept, idea and approach that require many changes in the traditional way of understanding and interpretation of energy management at all levels. Sustainable management of energy generated integrates many features of the environment. Sustainable energy management concept cannot therefore be construed as an adopted and defined the concept, but must be constantly modified and adjusted in accordance with changes in the three areas that define it, and in accordance with the specific country or region where applicable. Basically, the concept of sustainable energy defines the following parameters in the environment:

- Management and interpretation accepted theory, the existing experience, state regulations, navigation companies, the requirements of all stakeholders, level of education, awareness and commitment, and general orientation toward social responsibility;

- Energy. first of all legislation, existing energy resources, new energy resources, energy efficiency level, the level of technology development, production and consumption levels, system stability, connectivity with other systems, the degree of self-sufficiency:

- Sustainable development and acceptance of the concept at the state level, the ratification of the international agreement, the parameters of national sustainable development strategy, the list of priorities. 


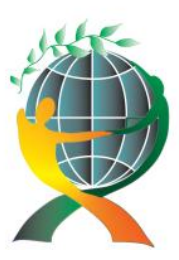

\author{
(online) $=$ ISSN $2285-3642$ \\ ISSN-L = $2285-3642$ \\ Journal of Economic Development, Environment and People \\ Volume 1, Issue 2, 2012 \\ URL: http://jedep.spiruharet.ro \\ e-mail: office jedep@spiruharet.ro
}

Accordingly, sustainable energy management can be defined as the process of energy management that is based on fundamental principles of sustainable development. Sustainable energy management must therefore be regarded as a concept that greatly deviates from the traditional management mode, which has largely ignored the need of preserving, restoring and saving energy resources. Thus conceived, the concept of sustainable energy management is a major global change whose effects is felt throughout the world community, and imposes a need for major changes in the mode of behavior and thinking, responsible institutions, as well as each individual. Therefore, the concept of sustainable energy management can be seen as a challenge of modern mankind, which opens up possibilities for proposals and development of many solutions that will have long term consequences for the development of human society as a whole.

Because of all this is necessary, or the only possible main issues of sustainable energy management approach taking into account the known scientific settings, practices and taking into account the characteristics of the entity that initiates, accepts and implements energy management in a sustainable manner. In general, sustainable energy management involves the implementation of a number of different activities aimed at concrete goals of sustainable development into practice, production, transmission and energy consumption.

Traditionally measured from the point of social and economic development of the utmost importance is the implementation of those measures and activities that bring the most effective results in less time, but with the acknowledgment of the principle of sustainability, an imperative of time becomes less significant. Eligible activities are those that bring high-quality results regardless of the time needed to detect and measure the positive effects.

Given the complexity and globalism of modern business, and taking into account a number of problems and disagreements in terms of global trends and priorities for development, sustainable energy management cannot be defined through a series of stringent actions to be undertaken, but modern science and practice show that the activity in the field of strategic and operational management, and improving quality, and socially responsible behavior in general, became imperative when it comes to the realization of the concept of sustainable energy development in practice.

The problem is the theoretical "gap between current and desired state." With that in mind, it is necessary to implement appropriate changes and implement appropriate activities to a company or community lead to a sustainable energy business and therefore will solve the problems of this kind. Phases to more responsible energy business are the following: 


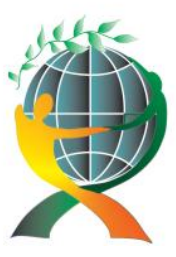

\author{
(online) $=$ ISSN $2285-3642$ \\ ISSN-L = $2285-3642$ \\ Journal of Economic Development, Environment and People \\ Volume 1, Issue 2, 2012 \\ URL: http://jedep.spiruharet.ro \\ e-mail: office jedep@spiruharet.ro
}

- Identification of problems (as a diagnostic activity), a specific phase for each company because each company is characterized by a number of differences and particularities in relation to other companies. If the management company set as the desired state of introduction of energysustainable business to a certain level (or completely), it should be in line with the objective to assess their own strengths and weaknesses defined. This is the stage set of company goals, which largely determines all other activities;

- Identification of development options, including prediction of activities that can be implemented to achieve the goals that are more energy-efficient dodnose business. While predictions of how that can achieve the set goals, each variant should be worked out in detail and realistic estimate. At this stage, a useful (but not critical) may experience companies in a similar situation;

- Choosing the most suitable variant leads to a set goal - energy responsibility. This phase involves making appropriate decisions (choice of several options offered) that determines the future course of action;

- Implementation of the chosen method to achieve the set objectives include a range of activities, requires the engagement of certain human resources, financial resources and time;

- Control and correction of deficiencies is a necessary activity that must be continuously carried out in order to timely correct the weaknesses and irregularities to which mainly comes from, no matter how many activities were planned in detail;

- Reaching the goal, which the company achieves a higher energy level of responsibility, which is certainly an appropriate way to inform all interested parties, especially consumers, owners and the community;

- Identification of (new) problem, thus returning to the beginning of activities and the company strives to improve its environmental activities on a suitable business to be continuous.

At all times relevant business service needs to monitor the situation in the region, which is primarily related to new requirements for energy-responsible business (which mostly come from consumers and legislators) and to initiate the previously mentioned activities. In all stages leading to the achievement of 


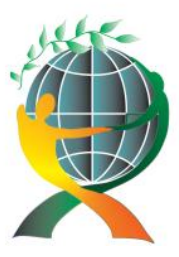

\author{
(online) $=$ ISSN $2285-3642$ \\ ISSN-L = $2285-3642$ \\ Journal of Economic Development, Environment and People \\ Volume 1, Issue 2, 2012 \\ URL: http://jedep.spiruharet.ro \\ e-mail: office jedep@spiruharet.ro
}

environmentally responsible businesses should be involved the whole management of the company, and if necessary, we can engage with the professionals.

Sustainable development itself is a kind of strategy of development of mankind which is restricted upon its particular, is subject to changes and adjustments. The effects of such development can be precisely measured at a certain point. But unlike traditional management, there is no strict orientation to reaching your goals. In fact, sustainable development is not defined in time and space, and involves constant improvement and improvement of, so it is not possible to reach a certain goal and then stop the implementation of sustainable development management process. Sustainable development is not a goal in itself, but a process that aims to continuously redefine and modify.

Thus defined the process of sustainable development makes it necessary for the application of certain traditional strategic management activities, enabling implementation and process control during the duration of which is practically unlimited. Sustainable energy management is not a very simply application of traditional methods of strategic management, but is their modification, which led to the development of a unique model of sustainable management that differs from the traditional and important measure questioned the justification of its implementation when it comes to sustainable management in the field of energy.

In order to design a strategy for sustainable energy development is above all necessary to set specific priorities for development. It is suggested five basic implementation of priority programs, which are diverse according to program content, but complementary from the standpoint of coordinating the operation and development of the whole energy system that is energy production sectors and the sectors of energy consumption and a gradual but consistent realization of the goals promoted in the future implementation of the proposed strategy.

- First-priority basic continuity of the technological modernization of existing power plants / systems / sources, in the sectors of oil, natural gas, coal with surface and underground mining, electric power sector, with manufacturing facilities: thermal, hydro and thermal power plant and transmission system or distribution systems, both the heat-district heating and industrial power plants.

- Second Priority-oriented rational use of energy quality and energy efficiency in production, distribution and use of energy by end users of energy services. 


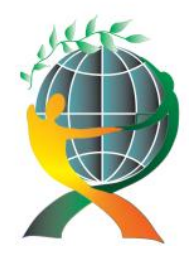

\author{
(online) $=$ ISSN $2285-3642$ \\ ISSN-L = $2285-3642$ \\ Journal of Economic Development, Environment and People \\ Volume 1, Issue 2, 2012 \\ URL: http://jedep.spiruharet.ro \\ e-mail: office jedep@spiruharet.ro
}

- Third-specific priority use NRSE (new renewable energy sources) and new energy-efficient and environmentally friendly energy technologies and devices / equipment energy use.

- $\quad$ Fourth-optional priority for the emergency / urgent investment in new power sources, with new gas technologies (combined gas-steam power plants).

- The fifth-long term development and regional strategic priority, building new energy infrastructure facilities and electric power and heat sources within the energy sector, and capital-intensive energy infrastructure.

\title{
3. Future directions of sustainable energy management
}

Time dimension of the energy problem is particularly pronounced as huge especially by means of energy management, and consequences which consequently may occur. Meeting the demand for energy exists throughout the modern history of mankind. Over time they grew need emerged as new ways for faster and more efficient use of energy resources, but the situation at the end of the twentieth century led to the need for this trend of uncontrolled energy review, slow down and redefined in ways that would be consistent with the concept of sustainable development.

The future in the field of energy management is defined in a way that clearly distinguished commitment must slow down the exploitation of nonrenewable resources, that energy must be used efficiently and that all users have to adapt to the energy business and a new way of thinking.

These fundamental changes in the energy management are exceptionally complex, comprehensive, linked with a number of smaller and larger changes in all spheres of work and thinking. It is necessary to redefine the existing legislation, adopt appropriate strategies at global and national levels, adjusted for each business entity and individual consumers. Changes in energy management changes related to the global community as a whole, but also to every individual.

In addition to the time required to implement sustainable energy management strategies, in order to select the type of strategic implementation is necessary to consider the size and strategic problems. The energy problem is global, with an upward trend. It features a number of factors, which are primarily related to the increase in global energy demand, uneven distribution of energy resources, and expressed high degree of dependence modern man of his energy is available. Problems with the power lead to minor or major problems in economy, society, relations between countries and relations in the global community. It is expected that the scale of these problems in the future, perhaps larger and more complex battle. It is 

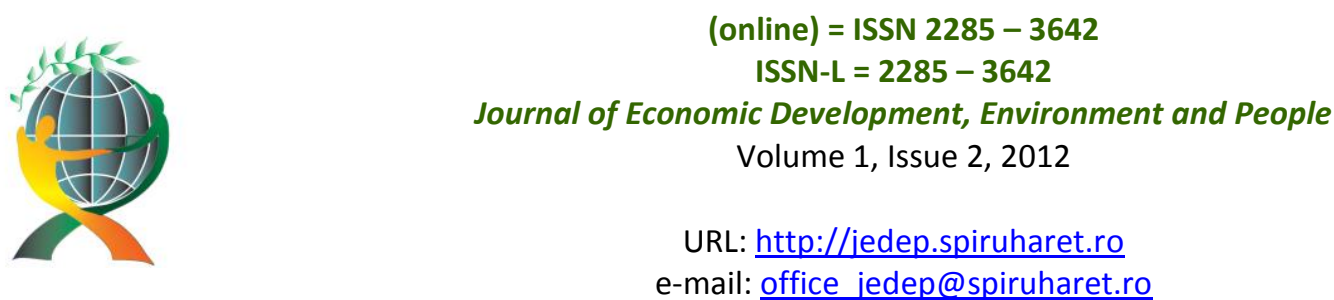

therefore quite correct to assume that the energy problem is one of the largest and most complex strategic problems facing our civilization.

Respect the time frame and estimate the size of the energy problem can be given to the proposal of possible ways to implement sustainable energy, as shown in Figure 2.

Time for change implementation

\begin{tabular}{|c|c|c|c|}
\hline & & Long & \\
\hline \multirow{2}{*}{$\begin{array}{c}\text { The size of the } \\
\text { strategic } \\
\text { issues }\end{array}$} & Great & $\begin{array}{l}\text { Sequentila } \\
\text { intervention }\end{array}$ & $\begin{array}{c}\text { Complex } \\
\text { intervention }\end{array}$ \\
\hline & Small & $\begin{array}{l}\text { Evolutionary } \\
\text { Intervention }\end{array}$ & $\begin{array}{c}\text { Contorl } \\
\text { intervention }\end{array}$ \\
\hline
\end{tabular}

Fig. 2: Types of possible implementation strategies for sustainable energy management

When a company is faced with small problems (small energy consumers) a period of time that it is available is not long enough, the implementation strategy will include a gradual or evolutionary (incremental) changes. If you have problems the company faces a small but a short time for which it is necessary to solve the resulting problem, which usually occurs in cases where the adopted new regulations that sharply define the changes in energy consumption, the activities carried out management (management action) directly to places where the problems began.

In cases where the company is a large manufacturer or a consumer of energy, should be especially careful to approach the selection of ways to implement sustainable energy strategies. Depending on how much time the organization has to solve the problem, there are two possible strategies. If the company is available a long time and emerging issues are large, it is sequential intervention or action in stages. However, if they are problems that cannot wait, apply a complex intervention and the management company must be fit (synchronized) changes in all parts of the enterprise.

In the sphere of energy problems may be that they have more or less potential impact on the situation in enterprises or a country as a whole, which largely depends on the resources which the country has and the way in which energy is being spent. Sustainable Development Strategy defines the energy problems in 


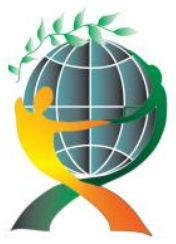

\author{
(online) $=$ ISSN $2285-3642$ \\ ISSN-L = $2285-3642$ \\ Journal of Economic Development, Environment and People \\ Volume 1, Issue 2, 2012 \\ URL: http://jedep.spiruharet.ro \\ e-mail: office jedep@spiruharet.ro
}

general as an area for which the essential need to solve a very long time, which is longer than the length of life for present generations and in addition there is a clearly defined position that the energy problems will never be able to fully resolve. The energy problem will be the constant companion of mankind for an indefinite period of the future.

A selected strategy for sustainable energy management is a highly complex process subject to the action of many influences. On the other hand, despite the clear front delimited proposed models for energy management, it is often not possible to select and implement a strategy without intermediate changes and adjustments. In addition, changes in the energy sphere are very numerous and diverse, and their impact on the sustainable management of energy is often associated with a host of economic and political change. Because of this, there are difficulties in trying to in some way to clearly define sustainable energy management. Every possible definition can be proposed redefined and vary depending on many factors.

\title{
4. Acknowledgements
}

This study is part of the project Interdisciplinary Research: No. III 47009 - Basic Research No. 179015 Challenges and Prospects of structural changes in Serbia: strategic directions for economic development and harmonization with EU requirements and project of Basic Research No. 179015 - Challenges and Prospects of structural changes in Serbia: strategic directions for economic development and harmonization with EU requirements which is supported by the Ministry of Science and Technological Development of Serbia in the period 2011-2014. The authors are grateful for the financial support.

\section{Conclusion}

In line with these priorities, the implementation of which will let the achievement of sustainable energy systems in the world, it is necessary to access the implementation of local, national programs that will be defined in line with the new strategic approach to energy management. The traditional approach to strategic management is not fully acceptable for sustainable management.

The actual planning process should be concrete actions (implementation strategies) and planning decisions are only an intermediate stage of the planning process. Through the implementation of the strategy, the company implemented the ideas of concrete achievements. In the process of formulating strategy came to the forefront of entrepreneurship and visionary qualities of leaders, while in the process of implementation is important that the skills of human resources with the help realize those goals. Modern business is characterized by continuous change. Magnitude of the problem caused by change and speed needed to solve the problem, determine the complexity and speed of implementation strategies. Depending on the size of the company and the division of management style there are several approaches to 


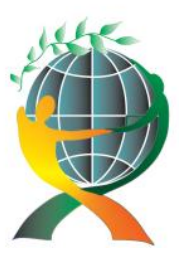

\author{
(online) $=$ ISSN $2285-3642$ \\ ISSN-L = $2285-3642$ \\ Journal of Economic Development, Environment and People \\ Volume 1, Issue 2, 2012 \\ URL: http://jedep.spiruharet.ro \\ e-mail: office jedep@spiruharet.ro
}

implementing the strategy. Each of the approaches has advantages and disadvantages, and the task of strategic management is that, depending on the size changes caused by implementation of selected strategies and other conditions, creates a flow of implementing the strategy.

Implementation of strategic orientation is not a single process but a process that involves the provision and allocation of resources, creation of organizational, procedural, and other motivational conditions and making a series of individual plans for undertaking and coordinating activities for the realization of these goals. Implementing the strategy involves a complex process of creating conditions and integration activities to be realized the expected results. For the proper management of activities it is necessary to specify the responsibility and authority, to identify tasks and budget and allocate them to the carriers through a system of coordination and overall management of the implementation process. In this case, emphasis is placed on global issues affecting the implementation of the strategy. The major issues are concerning to the creation of appropriate organizational structures and business culture of the company, transforming the long-term objectives in the current levels of performance, management and implementation activities of the process control and audit strategy.

Sustainable energy management is an extremely complex process, both in phase and Preparation of planning and in implementation phase.

\title{
6. References
}

[1] Todorović, J., Đuričin, D., Janošević, S., Strategic Management, Faculty of Economics, Belgrade, 2003. (in Serbian)

[2] Golušin, M.: Ecomanagement, monograph, The Faculty of Entrepreneurial Management, Novi Sad, 2006. (in Serbian)

[3] Munitlak Ivanović, O.: Strategic Management, University Educons, Sremska Kamenica, 2009. (in Serbian)

[4] Golušin, M., Tešić, Z., Ostojić, A.: The Analysis of the Renewable Energy Production Sector in Serbia, Renewable and sustainable energy review, Vol 14, Issue 5, pg 1477 - 1483, 2010.

[5] Golusin, M., Munitlak Ivanovic, O.: Definition, characteristics and state of indicators of sustainable development in countries of Southeastern Europe, Agriculture, Ecosystems and Environment, vol. 130, issues 1-2, 67-74, 2009.

[6] Munitlak Ivanovic, O., Golusin, M., Dodic, S., Dodic, J.: Perspectives of sustainable development in countries of Southeastern Europe, Renewable and sustainable energy review, Vol. 13, Issue 8, pg 2179-2200, 2009.

[7] Golušin, M., Munitlak Ivanovic, O., Bagaric, I., Vranjes, S.: Exploitation of geothermal energy as a priority of sustainable energetic development in Serbia, Renewable and sustainable energy review, Vol 14, Issue 2, pg 868$871,2010$. 


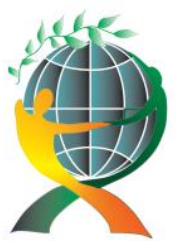

$$
\begin{gathered}
\text { (online) }=\text { ISSN 2285 - 3642 } \\
\text { ISSN-L }=2285-3642 \\
\text { Journal of Economic Development, Environment and People } \\
\text { Volume 1, Issue 2, } 2012
\end{gathered}
$$

URL: http://jedep.spiruharet.ro e-mail: office jedep@spiruharet.ro

[8] Golušin, M., Munitlak Ivanovic, O., Teodorovic, N.: The review oh achieved degree of sustainable development in South Eastern Europe - The use of linear regression method, Renewable and sustainable energy review, (in press), 2010.

[9] Munitlak Ivanovic, O., Golusin, M.: Kyoto protocol implementation in Serbia as precognition of sustainable energetic and economic development, Eneegy Policy, in press

[10] Rodriguez, L., C., May, B., Herr, A.: Biofuell excision and the vability of ethanol production in the Green Triangle, Australia, Energy policy, in press

[11] Faaij, A., P., C.: Bio-energy in Europe: Changing technology choices, Energy policy, Vol 34, Issue 3, 2006, pg 322-342 